\title{
24. TOTAL SULFUR CONTENTS OF BASALTS FROM DSDP LEG 34
}

\author{
Carleton B. Moore and Charles Lewis, Center for Meteorite Studies, Arizona State University, Tempe, Arizona \\ and \\ T.E. Bunch, NASA-Ames, Moffett Field, California
}

Total sulfur contents of basalt samples were determined by the combustion of powdered samples with oxygen in an induction furnace followed by the iodimetric titration of $\mathrm{SO}_{2}$ produced in a LECO model 532 automatic titrator.

The results for 14 samples are given in Table 1 . The values range from 31 to $2000 \mu \mathrm{g} / \mathrm{g}$ total sulfur. The lower values are similar to sulfur contents reported in many subaerial basalts whereas the higher values approximate the high values reported by Moore and Fabbi (1971) for submarine basalt. Lunar basalt and gabbro also range between 400 to $3200 \mathrm{ppm}$ in total sulfur. The higher total sulfur contents of submarine basalt as compared to subaerial basalt are attributed to the lower loss of sulfur by degassing. It is also possible to have secondary enrichment of sulfides in submarine basalt as described by Vakhrusher and Prokoptser (1972).

In this particular study the specific relationships are difficult to assess. The sulfur contents of the samples do not necessarily correlate with observed sulfide contents. Perhaps sulfur, in addition to that amount contained in sulfides, is also present in alteration patches.

\section{REFERENCES}

Moore, J.G. and Fabbi, B.P., 1971. An estimate of the juvenile sulfur content of basalt: Contrib. Mineral. Petrol., v. 33, p. 118-127.
TABLE 1

Results for Fourteen Samples

\begin{tabular}{lcccr}
\hline Hole & Core & Section & $\begin{array}{c}\text { Interval } \\
(\mathrm{cm})\end{array}$ & $\begin{array}{c}\text { Total S } \\
(\mu \mathrm{g} / \mathrm{g})\end{array}$ \\
\hline 319 & 13 & 1 & $77-80$ & 65 \\
$319 \mathrm{~A}$ & 1 & 1 & $48-51$ & 1450 \\
$319 \mathrm{~A}$ & 2 & 1 & $111-114$ & 990 \\
$319 \mathrm{~A}$ & 3 & 1 & $78-81$ & 1770 \\
$319 \mathrm{~A}$ & 3 & 5 & $75-78$ & 1720 \\
$319 \mathrm{~A}$ & 5 & 1 & $20-22$ & 35 \\
$319 \mathrm{~A}$ & 6 & 1 & $93-98$ & 600 \\
$319 \mathrm{~A}$ & 7 & 1 & $121-124$ & 1680 \\
$320 \mathrm{~B}$ & 3 & 1 & $54-57$ & 110 \\
$320 \mathrm{~B}$ & 5 & bit & sample & 100 \\
321 & 14 & 1 & $42-45$ & 1690 \\
321 & 14 & 2 & $9-12$ & 870 \\
321 & 14 & 4 & $7-10$ & 1990 \\
321 & 14 & 3 & $7-10$ & 1280 \\
\hline
\end{tabular}

Vakhrusher, V.A. and Prokoptser, N.G., 1972. Primary magmatic formations in basalts from oceanic crust and inclusions of ultrabasic rocks in basalts: Internatl. Geol. Rev., v. 14, p. 125-135. 